811.163.41'276.6:796

811.163.41'373.45:811.111

https://doi.org/10.18485/sj.2020.25.1.42

ВАЛЕНТИНА В. БУДИНЧИТ *

Алфа БК Универзитет, Београд

Факултет за стране језике
Оригинални научни рад

Примљен: 15. 10. 2019.

Прихваћен: 15. 01. 2019.

\title{
О НАДИМЦИМА ФУДБАЛСКИХ РЕПРЕЗЕНТАЦИЈА У СРПСКОМ ЈЕЗИКУ У СВЕТЛУ АНГЛИЦИЗАЦИЈЕ И ЈЕЗИЧКЕ НОРМЕ
}

У овом раду бавимо се анализом једног специфичног лексичког корпуса у оквиру спортског регистра у српском језику, а то су надимци фудбалских репрезентација. Анализа је обухватила корпус од преко 80 надимака за укупно 43 репрезентације које су учествовале на претходна два светска првенства у фудбалу (2014. и 2018. године), а циљ је био да се опишу начини адаптације и семантичке особине поменутог лексичког корпуса у светлу англицизације и језичке норме. Енглески језик као интернационални језик спорта у овој анализи је означен као језик посредник, те је првенствено анализирана адаптација енглеских облика у српском језику. Анализа је показала да су надимци у српском језику у највећој мери адаптирани превођењем енглеских облика, док је преобликовање заступљено у много мањој мери. Иако је већина примера адаптирана у складу са основним принципима адаптације, уочили смо известан број примера код којих приликом адаптације ови принципи нису у потпуности испоштовани.

Кључне речи: спортски регистар, англицизација, надимци, фудбал, термини, адаптација, језичка норма.

"vvalentinab@yahoo.com 


\section{1. УВОД}

Интензиван утицај енглеског језика на српски који је присутан последњих деценија видљив је на свим новоима лингвистичке анализе како у области општег језика, тако и у стручним доменима. Језик спорта у том контексту веома је специфичан, јер је због ширине своје употребе на одређени начин истовремено део општег и стручног регистра у српском језику, што доприноси повећаном обиму енглеског утицаја, а тиме и већем броју могућих стандарднојезичких питања у оквиру различитих језичких сегмената који у њему постоје. Постојећи научни радови на тему утицаја енглеског језика на српски у области спорта највећим делом се односе на истраживања енглеског утицаја на формирање стручне спортске терминологије и углавном указују на потребу за системским приступом задатку стандардизације стручне терминологије у овој области (Будинчић 2018, Милић 2013а, Милић 2013б). Тема којом се бавимо у овоме раду разматра један врло специфичан језички сегмент у спортском регистру, а то су надимци страних фудбалских репрезентација у српском спортском језику, анализирајући их кроз призму енглеског као интернационалног језика спорта ${ }^{1}$ у улози језика посредника у процесу језичког преузимања. С обзиром на то да адаптација и правилна употреба страних имена често представља изазов говорницима српског језика, а да су надимци као посебна врста именовања веома специфичан лексички корпус, нарочито када је реч о надимцима у сфери фудбала (једног од најпопуларнијих спортова на свету), наш основни циљ био је утврдити начине адаптације ових језичких јединица у српском језику у светлу англицизације и језичке норме.

\section{2. ТЕОРИЈСКИ ОКВИР}

Надимци (nicknames) као језичка појава по први пут забележени су у 15. веку и представљали су језичке облике за додатно именовање којим се исказивала блискост, наклоност или подсмех према носиоцу датог надимка. Овај вид именовања обично настаје у друштвеним групама које чине међусобно блиски људи (чланови породице, чланови спортског тима, групе војника), а осим људи могу их имати градови, туристичке области, астрономска тела, новине, заставе и слично. (Кристал 2003: 152)

Надимци као лексичке јединице предмет су лингвистичких анализа у оквиру ономастике ${ }^{2}$ - научне дисциплине која се бави проучавањем порекла значења имена и њихове употребе на различитим географским подручјима. Неке од дисциплина које се налазе у њеном оквиру су: антропонимија (наука

\footnotetext{
${ }^{1}$ Више видети код Будинчић 2015.

${ }^{2}$ О ономастичкој терминологији и категоријама видети више код Шћепановића $(1997 ; 1998)$.
} 
о личним именима), хидронимија (наука о називима водених токова и површина), топонимија (наука о именима географских подручја). С обзиром на то да имена места и лична имена представљају најстарије и тиме најзначајније и за лингвистичка истраживања најрелевантније језичке облике, на њима се врло често заснивају хипотезе о историји језика, дијалектима и језичким породицама. У последње време ономастика се све више изучава у контексту социолингвистике, психолингвистике, прагмалингвистике и текстуалне лингвистике. (Бусман 1996: 835, Драгићевић 2010: 23)

\section{1. Досадашња истраживања}

О карактеристикама личних надимака на одређеним географским подручјима на нашем говорном подручју до сада је објављено више научних радова (Целић 1995, Петровић 1996, Пижурица 1998 и други).

У вези са надимцима у сфери спорта број спроведених истраживања је значајно мањи. Наиме, можемо издвојити само њих неколико у којима се директно или посредно анализирају надимци у овој области. О. Панић Кавгић (2016а; 2016б) истраживала је лексичку креативност у надимцима светских тенисера у радовима: Лексичка креативност у надимцима светских тенисера и Linguistic creativity at work: Nicknames of women tennis players. В. Будинчић (2015a) у раду O слободи језичког израза у спортском новинарству, говори о надимцима спортских тимова и навијача као врсти спортског жаргона. J. Јовановић (2010) у књизи Лингвистика и стилистика новинског умећа о надимцима спортских тимова говори у контексту антономазичних перифрастичних израза $^{3}$, који се у новинским текстовима често користе уместо личних имена спортиста и тимова. И на крају, иако није у дирекној вези са надимцима у спорту (али јесте у вези са страним утицајима у области креирања надимака), издвојићемо рад Елементи другог сустава у надимку Мире Менац-Михалић (1993), који говори о утицајима других језика и наречја на процес формирања надимака у хрватском језику на различитим лингвистичким нивоима.

\section{3. АДАПТАЦИЈА РЕЧИ И ИМЕНА У СРПСКОМ ЈЕЗИКУ}

У наставку ћемо се осврнути на основне принципе адаптације речи и имена у српском језику у односу на које ћемо размотрити примере из корпуса у оквиру анализе која следи.

${ }^{3}$ Више о антономазији, као стилској фигури личног имена, видети код Ковачевића (2000: 
Наиме, два основна начина адаптације страних лексема у српском језику су преобликовање, тј. адаптација на нивоу форме, и превођење (Прћић 2002; Прћић 2005; Хлебец 2009). Приликом адаптације на нивоу форме потребно је придржавати се основног правила нашег правописа, а то је да се речи пишу онако како се изговарају. Како бисмо испоштовали ово правило приликом адаптације потребно је да се реч која улази у наш језик обликује фонетски и граматички према нашој речи (Белић 1950, Правопис 2010). Нарочито је важно обратити пажњу на то како ће се писати гласови других језика које наш језик нема и како ће гласити номинатив једнине позајмљених речи у нашем језику. (Белић 1950: 110; Филиповић 19864). Упркос томе што Правопис (2010) искључује изворно писање речи, свакодневно сведочимо употреби управо таквих речи, које се називају сировим англицизмима (Прћић 2005)5. Са друге стране, да би превођењем било могуће прилагодити одређену реч потребно је да она буде праграматички, морфосинтаксички, семантички и економично преводива; а врсте преводних поступака које нам стоје на располагању су: дословно превођење, структурно превођење (калкирање), делимично структурно превођење (делимично калкирање) и функцијска апроксимација (Прћић 2002; Прћић 2005).

Када је реч о адаптацији имена, што је превасходно тема наше анализе, важно је истаћи да је основни начин њихове адаптације фонолошко, морфолошко и графолошко преобликовање, с тим да у случају када „географска и институционална имена садрже преводиве именице, придеве или предлошке синтагме [...], такви елементи подлежу превођењу [...], понекад у комбинацији са преобликовањем.” (Прћић 2005: 188; Прћић 2008: 19-39) Надимци као врста додатног именовања, такође је важно имати у виду, специфични су по томе што је значење које носе, у одређеном броју случајева, једна од најважнијих њихових карактеристика. Значење се, међутим, не може пренети у други језик адаптацијом на нивоу форме. Са друге стране, превођењем то јесте могуће.

Узимајући у обзир све наведено, у наставку ћемо размотрити начине адаптације надимака у оквиру одабраног корпуса.

${ }^{4}$ Према Филиповићу (1986: 168-152) адаптација лексема преобликовањем одвија се на фонолошком и морфолошком нивоу. Фонолошка адаптација врши се на основу изговора или ортографије модела и слободном трансфонемизацијом. Морфолошка адаптација може бити нулта, компромисна и потпуна у зависности од степена адаптације слободних и везаних морфема у оквиру лексема.

${ }^{5}$ О прилагођавању страних речи у српском (раније српскохрватском) језику на нивоу форме говорили су Филиповић $(1971 ; 1986)$ и Сурдучки (1978), између осталих. 


\section{1. Анализа корпусног материјала}

Корпус за анализу у овоме раду чинило је преко 80 надимака који се користе у српском језику, за укупно 43 фудбалске репрезентације из целог света које су учествовале на претходна два светска првенства у фудбалу (2014. и 2018. године). Корпусни материјал је прикупљен из дневне спортске штампе на српском језику, као и из бројних извора са интернета.

Пошто је енглески језик интернационални језик спорта, овај језик је означен као језик посредник у процесу језичког преузимања у оквиру издвојеног корпуса, те је анализа превасходно усмерена на контакт енглеског и српског језика, односно на начине адаптације енглеских облика надимака у српском језику. У одређеним примерима, где то анализа буде захтевала, биће назначена веза између облика у српском језику и изворног облика надимка. У складу са теоријским принципима у вези са превођењем и преобликовањем као начинима адаптације страних речи и имена у српском језику у анализи ћемо, уз навођење основних података који се тичу семантичке мотивисаности, сваки од надимака класификовати на основу врсте адаптације. У анализи ће бити коришћене следеће ознаке: [П] - превођење, [ПР] - преобликовање, [ПР - преобликовање изворног надимка, [CА] - сирови англицизам и [/] - назив без еквивалента у нашем корпусу:

- Алжир = Пустињске лисице[П] (по географском крајолику који доминира овом земљом и животињама настањеним на овом подручју); енгл. The Desert Foxes.

- Аргентина = Бело-небеско-плави[П], Небеско плаво-бели[П], Гаучоси[ПР ${ }_{n}$; енгл. White and Sky Blues; оригин. La Albiceleste; Los Gauchos.

- Аустралија = Сокеруси[ПР], Кенгури[П] (по животињи која је настањена на овом подручју); енгл. The Socceroos; Термин socceroos је сливеница настала од речи soccer (са значењем фудбал) и гоо (по аналогији на реч kangaroo).

- Белгија = Ђаволи[П], Црвени ђаволи[П] (по боји дресова); енгл. Red Devils.

- Босна и Херцеговина* = Змајеви (по босанскохерцеговачком везиру који је био познат по надимку Змај од Босне), Златни љиљани (по симболу на грбу Бошњака), Плаво-жути[/] (по боји дресова); енгл. Dragons[П], Golden Lilies[П].

- Бразил = Кариоке[/], Кањариноси[ПР канаринци[П]; Изабрани[П], Национални тим[П], Селекција[П]; енгл. The selection, Little Canary; оригин. Selecao, Canarinho.

- Чиле = Црвени[П] (по боји дресова); енгл. The Red One.

- Данска = Дански динамит[П] (по карактеристикама игре), Црвени динамит[/]; енгл. Danish Dynamite 
- Египат = Фараони[П] (по историјским владарима); енгл. The Pharaohs.

- Еквадор = Триколори[ПР], Жути[П]; енгл. The Tricolor, The Yellows.

- Енглеска = Горди Албион[/] (назив који су Енглезима дали Французи због дволичности Енглеза према својим савезницима), Три лава[П]; енгл. The Three Lions.

- Француска = Триколори[/], Галски петлови[/] (по томе што је петао један од симбола Француске), Плави[П]; енгл. The Blues.

- Гана = Црне звезде[П] (по симболу на застави); енгл. Black Stars.

- Грчка = Небеско плаво-бели[П]; енгл. Sky blue-white; оригин. Galanolefki; Остали називи у грчком и енглеском: оригин. Piratiko (енгл. The Pirate Ship) оригин. Ethniki (енгл. National).

- Холандија = Орање[ПР] (са значењем: наранџасти, по боји дресова), Наранџасти[П]; енгл. Clockwork Orange, The Flying Dutchmen.

- Хондурас $=$ Los Catrachos[CA] (по локалном, колоквијалном називу за домаће становништво); оригин. Los Catrachos.

- Хрватска* = Ватрени, Коцкасти, Шаховничари; енгл. The

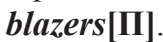

- Иран = Принчеви Персије[П] (по носиоцима угледних титула у Персији), Тим Мели[ПР ${ }_{\text {и }}$ (са значењем: национални тим); енгл. The Lions of Persia, The Iranian Lions, Lion Hearts, Persian Stars, Princes of Persia, The National Team; origin. Shirane Pars, Team Melli.

- Исланд = Викинзи[/] (по народној митологији), Наши момци[П]; енгл. Our Boys.

- Италија = Плави[П], Азури[ПР оригин. Gli Azzuri, La Nazionale.

- Јапан = Плави момци[П], Плави самураји[П]; енгл. Samurai Blue, Blue Samurai, Blue Boys.

- Јужна Кореја = Азијски тигрови[П], Црвени[П], Црвени ђаволи[П]; енгл. Red devils, Asian Tigers, The Reds, Taeguk Warriors.

- Камерун = Несавладиви лавови[П] (по краљевима животиња који насељавају ово подручје); енгл. The Indomitable Lions.

- Колумбија = Кафетероси[ПР $\left.{ }_{n}\right]$ (по узгоју кафе); енгл. The Coffee Growers; оригин. Los Cafeteros.

- Костарика $=$ Тикоси $\left[\boldsymbol{П Р}_{\mathbf{n}}\right]$ (по називу који означава домаће становништво у овој земљи); оригин. Los Ticos.

- Мароко = Лавови Атласа[П] (по подврсти лава који насељава Северну Африку); енгл. Atlas Lions.

- Мексико = Триколори[ПР $]$ ] (по бојама на застави), Тробојни[П] (по бојама на застави), Сомбрероси[/] (по популарним мексичким шеширима), енгл. El Tricolor, оригин. El Tri. 
- Немачка = Ди Маншафт[ПР грудни оклоп од гвожђа или челика), Елф[/] (по натприродним бићима из немачке митологије; на немачком значи и број 11); енгл. The Team, National Team, National Eleven; оригин. Die Mannschaft, Die Nationalmannschaft, Die Nationalelf.

- Нигерија = Супер орлови[П], Зелени орлови[П] (ранији назив, према симболу орла на врху грба тима); енгл. The Super Eagles, Green Eagles.

- Обала Слоноваче $=$ Слонови[П] (по животињама које насељавају ово подручје); енгл. The Elephants.

Остали називи на енглеском: The Tricolors, The Reds, The Selection.

- Панама = Каналџије[П] (по Панамском каналу), Црвена плима[П] (по боји дресова и морској појави); енгл. The Red Tide, The Canal Team.

- Перу = Инке[ПР] (по племену које је насељавало територију данашњег Перуа), Црвено-бели[П] (по боји дресова); енгл. The Incas, The White-Red.

- Пољска = Бели орлови[П] (по симболу орла на грбу), Црвенобели[П], енгл. The Polish Eagles, White-Reds.

- Португал = Селекција пет штитова[П] (по симболу на националном грбу, који потиче из времена краља Алфонса); Изабрани[П], Национални тим[/]; енгл. Team of the Castles, Team of the Five.

- Русија = Баћушке[/] (популаран надимак за Русе; значење: свештеник), Зборнаја команда[ПР $]$ ] (са значењем: заједничка екипа); енгл. Team; оригин. Sbornaya.

- САД = Јенки[ПР] (по колоквијалном називу за становнике Америке), Звезде и пруге[П] (по мотивима на застави); енгл. The Yanks; Stars \& Stripes; The Team.

- Саудијска Арабија = Зелени соколови[П] (по националној птици), Деца пустиње[П] (по географском крајолику); енгл. The Green Hawks/ Falcons; the Sons of the Desert.

- Сенегал = Лавови Теранге[П] (односи се на сенегалску гостољубивост); енгл. The Lions of Teranga; The Lions of Hispitality.

- Шпанија = Црвена фурија[П] (односи се на начин игре и квалитет тима); енгл. The Red Fury.

- Србија* = Орлови (по симболу на грбу), Плави (ранији назив, по боји дресова); енгл. The Eagles[П], The Blue[П].

- Швајцарска = Cајџије[/] (по популарним швајцарским сатовима), Нати[ПР ${ }_{n}$, Национални тим[П], Националманшафт[ПР ${ }_{n}$, Црвени крсташи[П] (по симболу на застави); енгл. The Red Crusaders, The Swiss National Team; оригин. The Schweizer Nati, Nationalmannschaft, Rossocrociati. 
- Шведска = Викинзи[/] (по племену које је некада живело на територији Шведске), Благулт[ПР $]$, Плаво-жути[П] (по боји дресова), Вундертим[ПР] (са значењем: чудесни тим); енгл. The Blue and Yellows; оригин. Blagult (са значењем: плаво-жути или плаво злато; назив се односи на боје заставе).

- Тунис = Орлови Картагине[П] (по томе што се Картагина некада налазила на територији данашњег Туниса); енгл. The Eagles of Carthage.

- Уругвај = Небеско-плави[П], Уруси[ПР $]$ (по староседелачком становништву); енгл. The Sky Blue One, A warrior tribe in Uruguay; origin. La Celeste, Charruas.

У вези са претходним примерима надимака можемо издвојити следеће закључке:

1. Начини адаптације надимака

- Највећи број надимака адаптиран је директним превођењем (51), потом следи преобликовање (19) и један пример са нултом ортографском адаптацијом (Los Catrachos).

- Надимци за репрезентације Србије, БиХ и Хрватске адаптирани су у енглеском језику превођењем (The Eagles, The Blue; Dragons, Golden Lilies; The Blazers).

- За неке од надимака у енглеском и српском језику нисмо пронашли еквиваленте (The Flying Dutchmen је надимак за холандску репрезентацију који се користи у енглеском језику, а у српском корпусу нисмо пронашли еквивалент за овај надимак).

- Одређени надимци настали су директним преобликовањем надимака из језика извора: Зборнаја, Ди Маншафт, Кафетероси.

С обзиром на то да је значење које носе веома важно својство које поседују неки од надимака, а оно се преобликовањем не може пренети у други језик, није изненађујућа чињеница да је основни начин адаптације у оквиру анализираног корпуса превођење.

Одређена одступања од основних принципа адаптације речи и имена присутна су у следећим примерима:

a) надимци који иако у себи садрже семантички, прагматички и морфосинтаксички преводиве лексеме адаптирани су преобликовањем: Тим Мели, Ди Маншафт, Вундертим.

б) употреба надимка са нултом ортографском адаптацијом: Los Catrachos.

За остале примере можемо констатовати да су адаптирани у складу са основним принципима адаптације речи и имена у српском језику и да облици у којима се јављају не одступају од норме српског правописа. 
2. Семантичке карактеристике надимака

- Надимци фудбалских репрезентација заснивају се на следећим мотивима: боје заставе или дреса (Наранџасти, Небеско-плави), географски елементи (Пустињске лисице, Лавови Атласа), историја и митологија ${ }^{6}$ (Викинзи, Фараони), симболи са грба и заставе (Звезде и пруге, Црне звезде), називи за домородачко становништво (Инке, Уруси).

- Стилска фигура на којој се заснивају неки од надимака јесте антономазија у којој се јављају елементи метонимије и метафоре (Азијски тигрови, Несавладиви лавови).

- Најмање су креативни надимци засновани на бојама заставе или дресова, као и надимци попут Селекција, Национални тим, Изабрани и сл., када термин који означава појам репрезентащије има функцију надимка.

- Једна репрезентација може имати више од једног надимка, при чему је творба сваког појединачно обично мотивисана потпуно различитим изворима (нпр. Сомбрероси и Триколори надимци су мексичке репрезентације).

- Популарност одређених надимака може бити различита на различитим територијама у зависности од значења које носе. Тако на пример, надимак за енглеску репрезентацију Горди Албион није популаран међу Енглезима јер има негативну конотацију. Са друге стране, Енглези за свој тим користе надимак Три лава.

- Одређени језички облици користе се као надимци за више различитих тимова истовремено (Триколори су репрезентације Мексика, Француске, Еквадора), што може негативно утицати на ефикасност у комуникацији у оквиру спортског регистра, односно фудбалског подрегистра.

\section{3. ОСТАЛА ЗАПАЖАЮА}

С обзиром на све претходно наведено, можемо закључити да анализирани надимци представљају веома комплексан и инспиративан лексички корпус. Наиме, поред контекста у оквиру кога је спроведена анализа надимака фудбалских репрезентација у српском језику у овоме раду, наведене лексичке јединице могу се посматрати и из неких других лингвистичких перспектива, и то као примери стилских фигура ${ }^{7}$ (пошто представљају 'онеобичајену употребу

${ }^{6}$ Иза неких од надимка крију се врло занимљиве приче у вези са одређеним историјским или митолошким детаљима, на којима се надимак заснива. Због ограниченог простора, у овоме раду те податке изнели смо само делимично, односно у мери у којој је то било неопходно за наше истраживање.

${ }^{7}$ Више о стилским фигурама видети код Ковачевића (2000). 
личног имена', дакле поседују критеријум одступағ $a$ који представља основ сваке стилске фигуре), затим као примери жаргона ${ }^{8}$ (јер представљају језичке облике који су креирани у оквиру једне специфичне друштвене групе, али и као примери својеврсних терминолошких јединица ${ }^{9}$ (јер представљају језичке ознаке које се користе у оквиру стручног регистра). Посебно је интересантно истаћи да комплексност семантичких одлика, које неки од анализираних надимака поседују, представља нарочито интересантно поље у оквиру кога би осим лингвистичких могла бити спроведена и различита социолошка, културолошка и друга истраживања.

\section{ЗАКљУЧАК}

Предмет овога рада били су надимци фудбалских репрезентација у српском језику у светлу англицизације и језичке норме. Корпус је чинило преко 80 надимака за укупно 43 фудбалске репрезентације које су учествовале на светском првенству у фудбалу 2014. и 2018. године. Премда није могуће са сигурношћу утврдити да ли су поменути надимци у облицима у којима се користе у српском језику директно или преко језика посредника ушли у српски језик, енглески језик као интернационални језик спорта у овој анализи означен је као језик посредник, те је првенствено анализирана адаптација енглеских облика у српском језику. Анализирајући начине адаптације, дошли смо до закључка да су надимци у највећој мери формирани превођењем, што је било и очекивано с обзиром на то да је значење које преносе врло често једна од њихових основних карактеристика, а превођење, за разлику од преобликовања, представља начин адаптације којим је могуће то значење пренети. Преобликовање као начин адаптације заступљено је у знатно мањој мери. У корпусу се издвојио одређени број надимака који нису адаптирани у складу са основним принципима адаптације речи и имена у српском језику, и то један надимак са нултом ортографском адаптацијом и неколико надимака који су адаптирани преобликовањем, иако у свом саставу имају елементе који би по семантичким, прагматичким и морфосинтаксичким особинама могли бити адаптирани превођењем. И на крају, важно је истаћи да овај лексички корпус врло аутентично и боље него било који други сегмент спортског језика одсликава различите глобалне утицаје који се у садејству језика и спорта као два глобална друштвена феномена на језичком корпусу остварују, те би као такав без сумње могао бити предмет бројних нових истраживања, како у сфери лингвистике тако и на другим пољима.

\footnotetext{
${ }^{8}$ Више о жаргону видети код Радовановића (1979).

${ }^{9}$ Више о треминологији видети код Драгићевићеве (2010), Шипке (1998), Бугарског (1996).
} 


\section{ЛИТЕРАТУРА}

Белић 1950: А. Белић, Правопис српскохрватског књижевног језика, Београд: Просвета.

Бугарски 1996: Р. Бугарски, Лингвистика у примени, Београд: Чигоја штампа.

Будинчић 2015: В. Будинчић, Енглески као интернационални језик спорта у времену (англо)глобализације, Српски језик, XX, 551-560.

Будинчић 2018: В. Будинчић, Англищизми у спортској терминологији, Београд: Алфа БК универзитет.

Бусман 2006: H. Bussmann, Routledge Dictionary of Language and Linguistics. London \& New York: Routledge.

Драгићевић 2010: Р. Драгићевић, Лексикологија српског језика, Београд: Завод за уџбенике.

Ковачевић 2000: М. Ковачевић, Стилистика и граматика стилских фигура, треће измењено и допуњено издање, Крагујевац: Кантакузин.

Кристал 2003: D. Crystal, Cambridge Encyclopedia of English Language, Cambridge: Cambridge University Press.

Менац Михалић 1993: М. Menac-Mihalić, Elementi drugog sustava u nadimku, FOC 2, 57-66.

Милић 2013a: M. Milić, Stvaranje, standardizacija i kodifikacija sportske terminologije u srpskom jeziku, Aktuelne teme engleskog jezika nauke $i$ struke u Srbiji, Beograd: CID Ekonomskog fakulteta u Beogradu, 77-90 [URL: http://www.academia.edu/5023686/Sila\%C5\%A1ki N._and_\%C4\%90urovi\%C4\%87_T._Eds._2013_.Aktuelne_teme_ engleskog_jezika_nauke_i_struke_u_Srbiji_Current_topics_in_English_for_specific_purposes_at_tertiary_level_in_Serbia_._Beograd. CID_Ekonomskog_fakulteta]

Милић 2013b: M. Milić, The influence of English on Serbian sports terminology, ESP Today, Vol. 1, Beograd, 65-79.

Панић Кавгић 2016а: О. Панић Кавгић, Лексичка креативност у надимцима светских тенисера, Годишњак Филозофског факултета у Новом Садy, XLI-1, 269-299.

Панић Кавгић 2016б: O. Panić Kavgić, Linguistic creativity at work: Nicknames of women tennis players, in: Vujin, B. and Radin Sabadoš, M. (eds.) (2016). The Third Conference on English Cultures and Anglophone Cultures Today (ELALT3), Proceedings, Novi Sad: Faculty of Philosophy. 
Петровић 1996: Н. Петровић, Надимци старих Нишлија, Зборник радова Филозофског факултета у Нишу, 4/5, 239-253.

Пижурица 1998: М. Пижурица, Заштитно име из локалне перспетиве, Фолклор у Војводини, 10, 69-73.

Правопис 2010: Правопис српскога језика, приредили М. Пешикан, Ј. Јерковић, М. Пижурица, Нови Сад: Матица српска.

Прћић 2002: Т. Прћић, Адаптација нових речи из енглеског језика превођењем, Примењена лингвистика, 3, Нови Сад, 95-101.

Прћић 2005: Т. Прћић, Енглески у српском, Нови Сад: Змај.

Прћић 2008: Т. Прћић, Нови транскрипщиони речник енглеских личних имена, Нови Сад: Змај.

Радовановић 1979: М. Радовановић, Социолингвистика, Београд: Београдски издавачко-графички завод.

Сурдучки 1978: M. Surdučki, Srpskohrvatski i engleski u kontaktu: Rečnik $i$ morfološka analiza engleskih pozajmljenica u standardnom srpskohrvatskom jeziku i jeziku Srba i Hrvata iseljenika u Kanadi, Novi Sad: Matica srpska.

Филиповић 1971: R. Filipović, Kontakti jezika u teoriji i praksi, Zagreb: Školska knjiga.

Филиповић 1986: R. Filipović, Teorija jezika u kontaktu. Uvod u lingvistiku jezičkih dodira, Zagreb: JAZU, Školska knjiga.

Хлебец 2008: B. Hlebec, Opšta načela prevođenja, Beograd: Beogradska knjiga.

Целић 1995: Р. Целић, Надимии Краљевчана, Краљево: Слово.

Шипка 1998: Д. Шипка, Основи лексикологије и сродних дисииплина, Нови Сад: Матица Српска.

Шћепановић 1997: М. Шћепановић, Ономастичке категорије и српска ономастичка терминологија, Кюижевност и језик, XLV/2-3, 65-69.

Шћепановић 1998: М. Шћепановић, Категоризација врста ријечи у ономастичкој номинацији, Научни састанак слависта у Вукове дане, 27/2, 287-297.

\section{Извори}

https://www.topendsports.com/sport/soccer/team-nicknames.htm https://www.srednja.hr/sport/sport-sport/nadimci-svih-reprezentacija-koje-ce-nastupiti-na-ovogodisnjem-svjetskom-nogometnom-prvenstvu/ 
http:/www.skysports.com/football/news/11095/11309560/world-cup-2018-whatare-the-nicknames-of-the-teams-in-russia

http://mentalfloss.com/article/54205/nicknames-all-32-world-cup-2014-teams

http://novilist.hr/Sport/Nogomet/Znate-li-tko-su-Nasi-decki-a-tko-Lavovi-atlasaDonosimo-sluzbene-nadimke-svih-reprezentacija

https://www.srbijadanas.com/sport/fudbal/srbi-nisu-jedini-jos-dve-selekcije-zovuorlovi-ovo-su-svi-nadimci-ucesnika-mondijala-foto-2017-11-13

\section{ON THE NICKNAMES OF FOOTBALL NATIONAL TEAMS IN SERBIAN LANGUAGE IN THE LIGHT OF ANGLICIZATION AND LANGUAGE NORMS}

\section{Summary}

The paper deals with the specific lexical units within the sports register in the Serbian language, and these are the nicknames of football national teams. The analysis included a corpus of over 80 nicknames for a total of 43 teams participating in the previous two world football championships (in 2014 and 2018). The aim was to describe the models of adaptation and semantic features of the chosen lexical corpus in the light of anglicization and language norm. The English language as the international language of sports is marked as a language mediator in this analysis, and the adaptation of English forms in the Serbian language is primarily analyzed. The analysis showed that the nicknames in the Serbian language are mostly adapted by translation of the English language forms, while the transformation is employed to a much lesser degree. Although most of the nicknames have been adapted in accordance with the basic principles of adaptation, we have noticed a number of examples in which these principles were not fully respected during the adaptation.

Keywords: sports register, anglicization, nicknames, football, terms, adaptation, language norm 